Article

\title{
Synthesis and Characterization of Glutamic-Chitosan Hydrogel for Copper and Nickel Removal from Wastewater
}

\author{
Huda E. Abdelwahab, Seham Y. Hassan, Mohamed A. Mostafa and Mohamed M. El Sadek* \\ Chemistry Department, Faculty of Science, Alexandria University, Alexandria 21231, Egypt; \\ Ehuda_eid@yahoo.com (H.E.A.); sehamyassen@yahoo.com (S.Y.H.); mabdelzaher15@yahoo.com (M.A.M.) \\ * Correspondance: elsadek_mm@yahoo.com or mohamed.elsadik@alexu.edu.eg; Tel.: +20-010-065-446-17
}

Academic Editor: Massimiliano Fenice

Received: 24 March 2016; Accepted: 20 May 2016; Published: 25 May 2016

\begin{abstract}
Chitosan was reacted with four concentrations (2.5, 5, 10 and $20 \mathrm{mmol})$ of glutamic acid resulting in four types of glutamic-chitosan hydrogels (GCs), the activity of the resulted compounds on the removal of copper(II) and nickel(II) from wastewater were tested. The results indicated that by increasing glutamic acid concentration from GCs-1 to GCs-4, the efficiency of removing $\mathrm{Cu}(\mathrm{II})$ and $\mathrm{Ni}(\mathrm{II})$ were decreased, which may be due to a decrease in the pore size of the hydrogels as a result of the increased degree of crosslinking.
\end{abstract}

Keywords: chitosan; wastewater; copper(II); nickel(II); glutamic acid

\section{Introduction}

The huge increase in the use of heavy metals over the past few decades has resulted in an unwanted increased presence of heavy metals in the environment, for example, industrial wastewater which contains high amount of heavy metals can pollute water resources. Heavy metals which include zinc, copper, nickel, mercury, cadmium, lead and chromium are one of the most toxic types of water pollutants. At least 20 metals are considered to be toxic and approximately half of these metals are emitted to the environment in quantities that are risky to the surroundings, in addition to the human health. A majority of heavy metals are non-biodegradable and highly toxic [1], so their concentrations have to be reduced to acceptable levels before discharge into the environment; otherwise, they can pose a threat to the health of animals and humans.

Wastewater containing heavy metals results mainly from metal plating facilities, mining operations, batteries, paper, fertilizer, tanneries, pesticide industries, stabilizers, thermoplastics, and pigment manufacture [2]. These industries discharge heavy metals directly or indirectly into the environment, especially in developing countries. Heavy metals tend to accumulate in living organisms [3] causing numerous diseases and disorders due to their toxicity and non-biodegradability [4]. Nickel is a chemically active metal used for preparing a large number of nickel alloys and also used in many other industries. The excessive intake of nickel may cause carcinogenesis, mutagenesis and dermatogenic effects as a result of bioaccumulation [5,6]. Copper $(\mathrm{Cu}(\mathrm{II}))$ is micronutrient element that plays an important role in bone formation together with certain proteins and enzymes [7]. However, the consumption of food or water containing high copper concentrations can cause several diseases such as gastrointestinal symptoms, liver toxicity, osteoporosis, Wilson's, and Alzheimer's diseases [8-10]. Excessive intake of copper can also cause hemolysis, hepatotoxicity, nephrotoxicity, vomiting, cramps, and convulsions [4].

The high cost and complexity, high energy consumption and secondary pollution problems [11] of most of the treatment processes that are used to remove heavy metals from wastewater are 
considered to be major problems [12]; for those reasons, a number of studies were carried out on the use of low-cost adsorbents for the removal of heavy metals from natural resources [13] such as chitosan, which also is a biodegradable and biocompatible polymer. Chitosan consists mainly of $\beta$ - $(1 \rightarrow 4)$-2-acetamido-2-deoxy-D-glucose units which are produced by deacetylation of chitin [14]. Chitosan is the second most abundant biopolymer on Earth after cellulose [15], it is widely distributed in crustacean shells and cell walls of fungus. Several methods have been reported for the chemical modification of chitosan, one of which is the crosslinking of chitosan with various substances such as dialdehydes and dicarboxylic acids. Chitosan was modified with several dicarboxylic acids including glutamic acid by reacting both carboxylic acid groups with the amino groups of chitosan [6]. In the present work, chitosan was reacted with four different amounts of glutamic acid, resulting in four types of glutamic-chitosan (GC) hydrogels, the resulting crosslinking polymers were tested for the removal of copper(II) and nickel(II) from wastewater.

\section{Results and Discussion}

\subsection{Synthesis of Glutamic-Chitosan Cross Linked Hydrogels (GCs)}

Chitosan was modified with glutamic acid, whereby the carboxylate groups of glutamic acid reacted with the amino groups of chitosan (Scheme 1). The amount of glutamic acid with respect to chitosan was varied to produce four new cross-linked glutamic-chitosan hydrogels (Scheme 1) designated as: glutamic-chitosan-1 (GCs-1), glutamic-chitosan-2 (GCs-2), glutamic-chitosan-3 (GCs-3), and glutamic-chitosan-4 (GCs-4) with increasing degrees of cross linking, respectively. All the prepared derivatives are produced in a nearly quantitative yield (89\%-96.4\%).

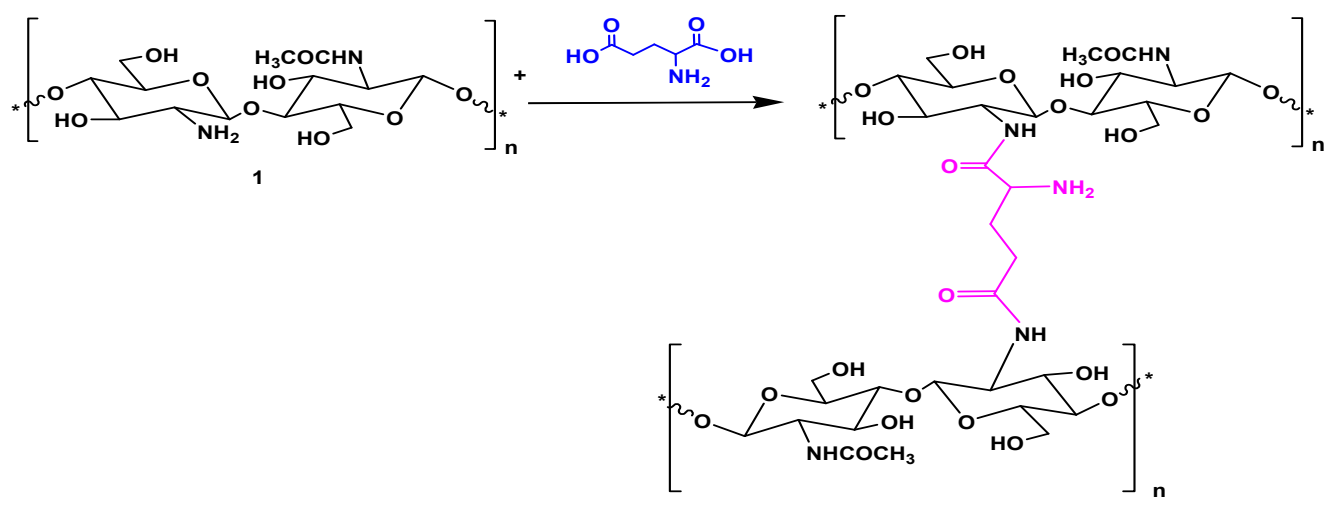

Scheme 1. Synthesis of glutamic-chitosan hydrogel.

The modification of chitosan with crosslinking reactions leads to formation of chitosan derivatives with better resistance in extreme media conditions [16]. On the other hand, the crosslinking modification slightly decreases the adsorption capacity of chitosan; to overcome this difficulty we choose glutamic acid as crosslinker since glutamic acid will increase the amino $\left(-\mathrm{NH}_{2}\right)$ and the carbonyl $(\mathrm{C}=\mathrm{O})$ groups [17]. Increasing the abundance of these groups in the target molecule will facilitate increased complex formation with $\mathrm{Ni}(\mathrm{II})$ and $\mathrm{Cu}(\mathrm{II})$. The proposed adsorption mechanism of $\mathrm{Ni}$ (II) and $\mathrm{Cu}(\mathrm{II})$ on chitosan-glutamic hydrogel is illustrated in Scheme 2.

\subsection{Fourier Transform Infrared Spectroscopy (FTIR) Characterization of G-Cs}

Glutamic-chitosan formation was confirmed using Fourier transform infrared spectroscopy. The FTIR spectrum of chitosan showed four strong absorption peaks at 1157.8, 1076.6, 1030, and $895.7 \mathrm{~cm}^{-1}$ which are characteristic peaks of the saccharide structure, where the $\mathrm{OH}$ and $\mathrm{NH}$ functions showed a very strong broad absorption peak around $3600-3200 \mathrm{~cm}^{-1}$. Primary amines showed two absorption peaks at 1650.4 and $1598.9 \mathrm{~cm}^{-1}$, which indicated that chitosan had a high degree of deacetylation [18]. 
The FTIR spectra of the GC hydrogels showed the broad band between 3450 and $3470 \mathrm{~cm}^{-1}$ due to the $\mathrm{OH}$ and $\mathrm{NH}$ groups. In addition, the characteristic absorbance of $\mathrm{NH}_{2}$ at 1650.4 and $1598.9 \mathrm{~cm}^{-1}$ was also seen. The spectra also showed a broad absorption band around $1637 \mathrm{~cm}^{-1}$ which corresponds to the $(\mathrm{CONH})$ amide group, and the intensity of this band increased with increasing cross-linking density of the hydrogels, i.e., from GCs-1 to GCs-4 (see Table 1).
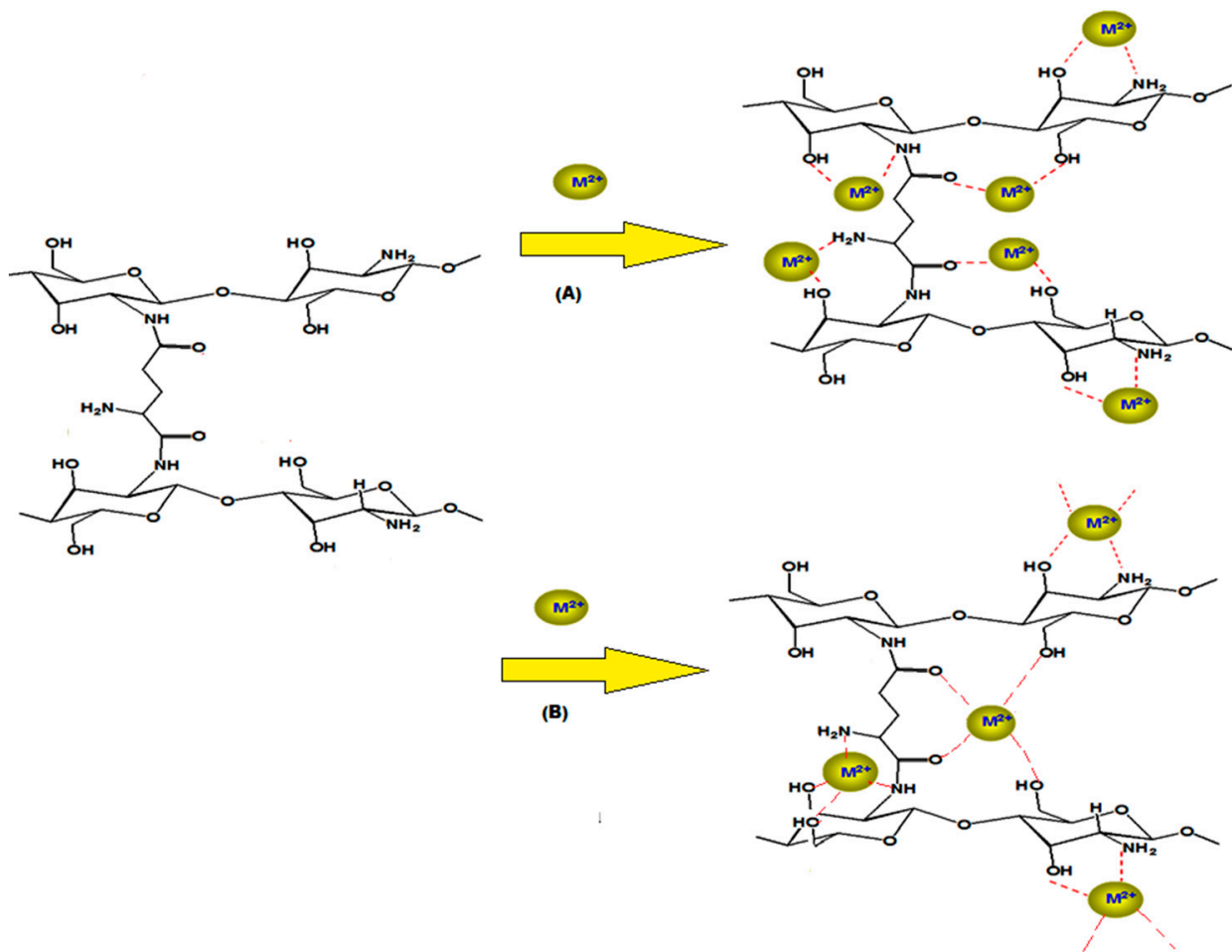

Scheme 2. The proposed mechanism, $\mathrm{M}^{2+}$ for (A) nickel and (B) copper.

Table 1. IR spectral data of compounds 1-4.

\begin{tabular}{cc}
\hline Compound & IR $\left(\gamma, \mathbf{c m}^{-\mathbf{1}}\right)$ \\
\hline GCs-1 & $1635(\mathrm{CONH}), 3465(\mathrm{NH}), 3465 \mathrm{~cm}^{-1}(\mathrm{OH})$ \\
GCs-2 & $1637(\mathrm{CONH}), 3458(\mathrm{NH}), 3458 \mathrm{~cm}^{-1}(\mathrm{OH})$ \\
GCs-3 & $1637(\mathrm{CONH}), 3467(\mathrm{NH}), 3467 \mathrm{~cm}^{-1}(\mathrm{OH})$ \\
GCs-4 & $1638(\mathrm{CONH}), 3467(\mathrm{NH}), 3467 \mathrm{~cm}^{-1}(\mathrm{OH})$ \\
\hline
\end{tabular}

\subsection{Elemental Characterization of GCS}

Elemental analyses of the GC derivatives is another confirmation of GC formation; the elemental analysis data are shown in Table 2.

Table 2. Elemental analyses and \% yield of G-chitosan hydrogels.

\begin{tabular}{ccccc}
\hline \multirow{2}{*}{ Compound } & \multicolumn{3}{c}{ Elemental Analyses } & \multirow{2}{*}{ Yield \% } \\
\cline { 2 - 4 } & $\mathbf{\%} \mathbf{C}$ & $\mathbf{\% ~} \mathbf{H}$ & $\mathbf{\% ~ N}$ & \\
\hline Cs & 45.10 & 6.77 & 8.43 & - \\
GCs-1 & 47.80 & 7.15 & 7.69 & 96.4 \\
GCs-2 & 47.84 & 7.24 & 7.72 & 92.5 \\
GCs-3 & 47.86 & 7.27 & 7.74 & 90.2 \\
GCs-4 & 47.88 & 7.35 & 7.77 & 89 \\
\hline
\end{tabular}




\section{4. ${ }^{1} \mathrm{H}-\mathrm{NMR}$ Characterization of GC Hydrogels}

The structure of compounds GCs- 1 to GCs-4 is further proved by ${ }^{1} \mathrm{H}-\mathrm{NMR}$ spectroscopy, which showed the two $(\mathrm{NH})$ protons as a singlet at $\delta 7.77$, the $1^{\prime}-\mathrm{OH}$ proton at 4.00 , and the rest of the sugar protons at the range 3.29-3.33 ppm, as well as the appearance of the two $\left(\mathrm{NH}_{2}\right)$ protons $\mathrm{f}$ at 3.29 (see Experimental). After shaking of compounds 1-4 with $\mathrm{D}_{2} \mathrm{O}$, their ${ }^{1} \mathrm{H}-\mathrm{NMR}$ spectra showed the disappearance of the $\left(\mathrm{NH}_{2}\right)$ and $(\mathrm{NH})$ protons as well as $(\mathrm{OH})$ protons [18].

\subsection{Scanning Electron Microscopy Observations of G-Chitosan Hydrogels}

Microstructures of the hydrogels surface were investigated by scanning electron microscopy as presented in Figure 1. It could be seen that the hydrogels have a similar surface appearance, but the distribution and the size of their pores are different. The porosity distribution became more uniform and dense with increasing concentration of glutamic acid.

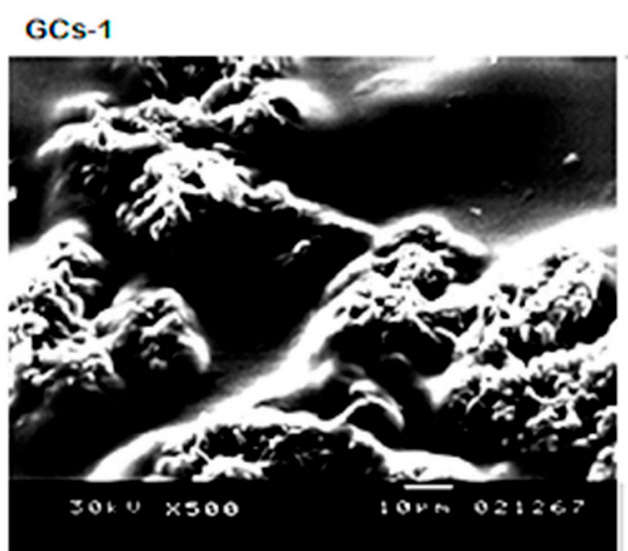

GCs-3

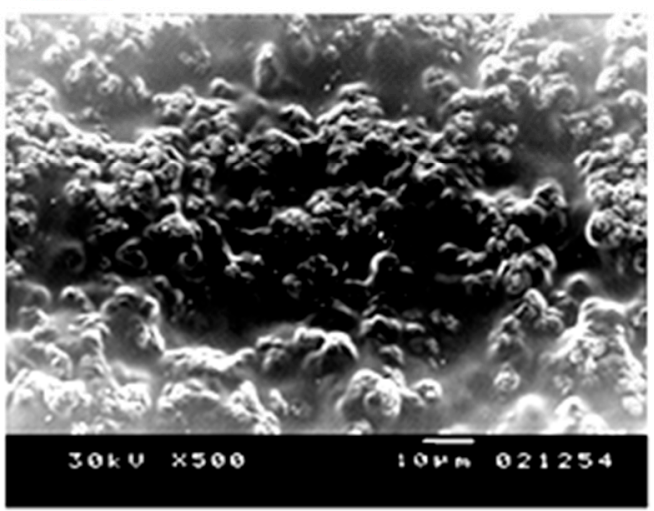

GCs-2

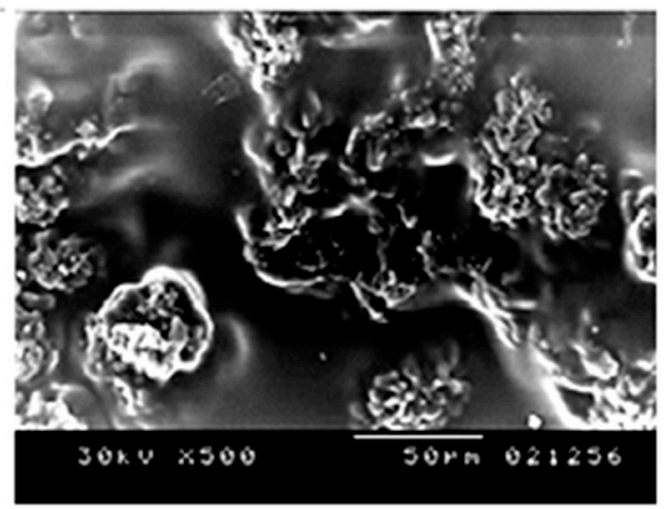

GCs-4

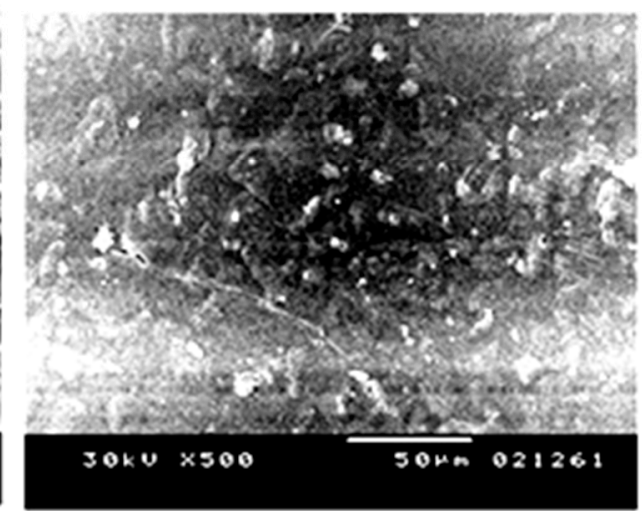

Figure 1. Scanning electron microscopy of G-chitosan hydrogels.

The extremely porous surface structure of the hydrogels could lead to high surface areas. The pore size of the hydrogels decreased with increasing the cross-linking density of the hydrogels from GCs-1 to GCs-4 hydrogel.

\subsection{Solubility of G-Chitosan Hydrogels}

The solubility of the new hydrogels was studied in different solvents at room temperature. The results show that the hydrogels are insoluble in acetic acid solution $(1 \% v / v)$, dimethylformamide, dimethyl sulfoxide, tetrahydrofuran, $N$-methylpyrrolidone, chloroform, methylene chloride, acetone and methanol since no soluble fractions of the hydrogels were obtained. This indicates a successful formation of crosslinked networks in these hydrogels. 


\subsection{Sorption Studies of $\mathrm{Ni}(\mathrm{II})$ and $\mathrm{Cu}(\mathrm{II})$}

\subsubsection{Influence of G-chitosan Amount}

The dependence of $\mathrm{Ni}$ (II) sorption on G-chitosan amount was studied by varying the amount of the adsorbent from $1 \mathrm{~g}$ to $5 \mathrm{~g}$ while keeping the other parameters such as $\mathrm{pH}$, metal solution volume $(100 \mathrm{~mL})$, concentration $(200 \mathrm{mg} / \mathrm{L})$, and contact time $(60 \mathrm{~min})$ constant. Figure 2A shows that the percentage removal of nickel increases with increasing adsorbent dose from $48 \%$ to $95 \%$.

Figure 2B shows that the removal efficiency of copper was improved on increasing adsorbent doses; this may occur due to the fact that the higher dose of adsorbents in the solution provides the greater availability of exchangeable sites for the ions. The maximum $\%$ removal of $\mathrm{Cu}$ (II) was $95.17 \%$ at the dosage of $250 \mathrm{mg}$.
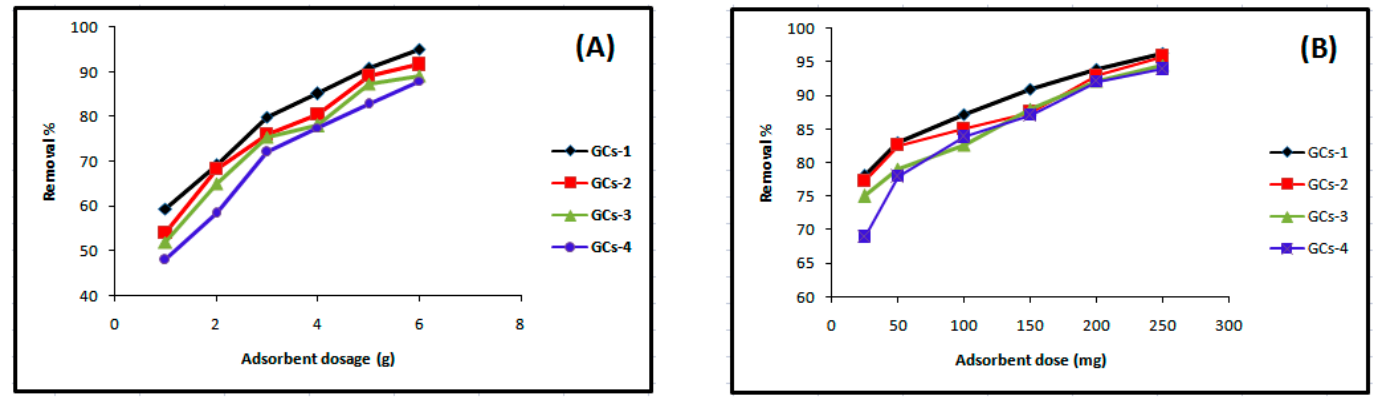

Figure 2. Influence of GCs amount on (A) nickel and (B) copper sorption.

\subsubsection{Influence of $\mathrm{pH}$}

The effect of $\mathrm{pH}$ on the adsorption of $\mathrm{Ni}$ is presented in Figure 3A. The $\mathrm{pH}$ of the aqueous solution is an important parameter in the adsorption process because it affects the concentration of the counter ions on the functional groups of the adsorbent, the solubility of the metal ions and the degree of ionization of the adsorbate during reaction [12]. The active sites on an adsorbent can either be protonated or deprotonated depending on the $\mathrm{pH}$ while at the same time the adsorbate speciation in solution depends on the $\mathrm{pH}$ too.
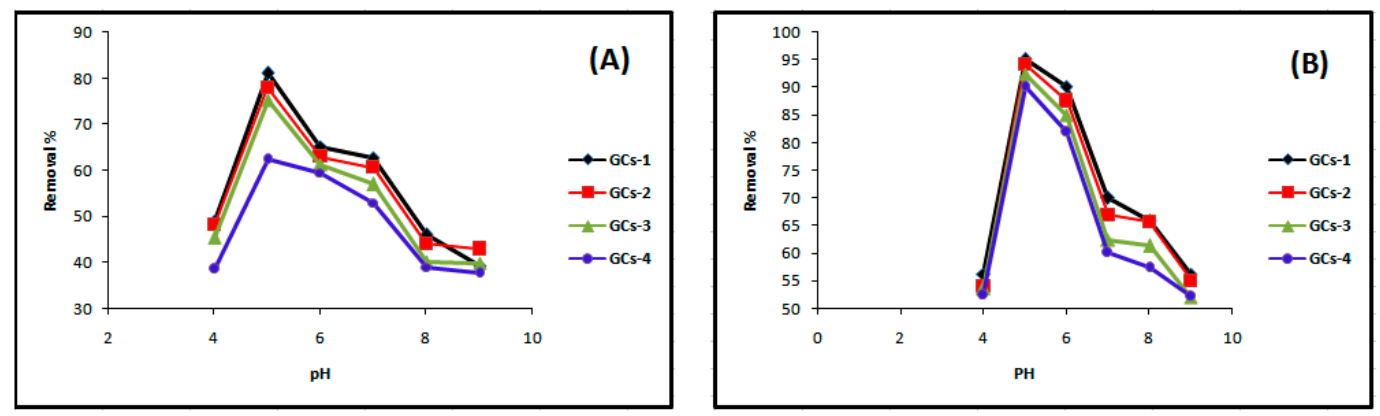

Figure 3. Influence of $\mathrm{pH}$ on (A) nickel and (B) copper sorption.

At low $\mathrm{pH}(2-4)$, less metal ion uptake was observed due to the competitive adsorption of the $\mathrm{H}^{+}$ and $\mathrm{Ni}(\mathrm{II})$ ions on the G-chitosan compounds surface. At low $\mathrm{pH}$ values, the adsorbent is positively charged with higher $\mathrm{H}^{+}$ion concentration, reducing the number of binding sites for metal ion (Figure 4). In addition, the protonation of amino groups in acidic solution induces an electrostatic repulsion of metal cations that reduces the number of binding sites available for metallic ions [13]. However, $\mathrm{Ni}$ (II) uptake increased as the $\mathrm{pH}$ increased to $\mathrm{pH}$ 9, as most active sites on the adsorbent are deprotonated resulting to a more net attractive force which is responsible for high nickel removal from aqueous solution. The optimum adsorption takes place at $\mathrm{pH} 5$. Further increase in $\mathrm{pH}$ leads to the precipitation of nickel hydroxide complexes which inhibits the adsorption process. 
Figure $3 \mathrm{~B}$ as shown above illustrated that $\mathrm{pH}$ obviously influenced the removal efficiency of the copper ions in the aqueous solution; the results indicated that $\mathrm{Cu}$ (II) removal was increased to maximum and then decreased with $\mathrm{pH}$ variation from 4 to 9 at $25^{\circ} \mathrm{C}$ and agitation speed of $100 \mathrm{rpm}$. The maximum \% removal of $\mathrm{Cu}$ (II) was $95 \%$ at $\mathrm{pH} 5$. The dominant species of copper was free $\mathrm{Cu}$ (II) and was mainly involved in the adsorption process when the $\mathrm{pH}$ was lower than 5 . With the $\mathrm{pH}$ greater than 5, copper ions started to precipitate as $\mathrm{Cu}(\mathrm{OH})$ [13]. Increases in metal removal with increased $\mathrm{pH}$ can be explained on the basis of the decrease in competition between proton and metal cations, which results in a lower electrostatic repulsion between surface and metal ions. Decrease in adsorption at higher $\mathrm{pH}(>5)$ is due to the formation of soluble hydroxyl complexes [15].
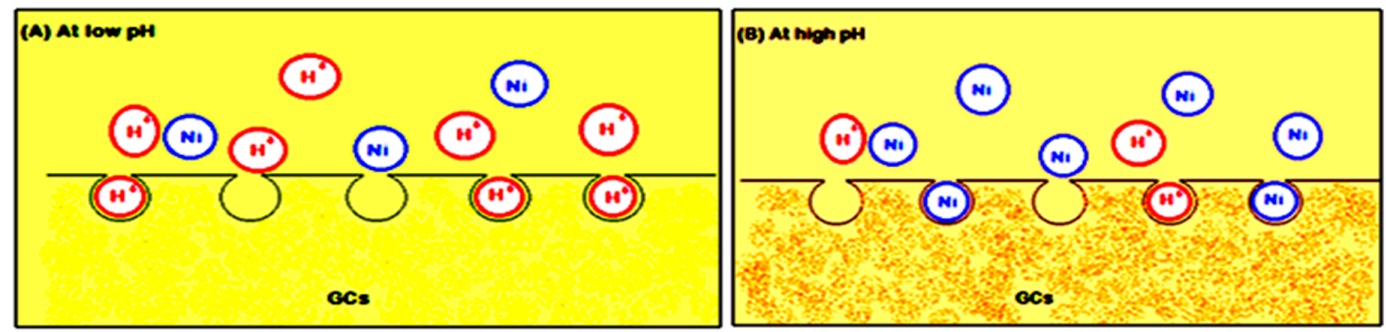

Figure 4. Metal ion uptake (A) at low $\mathrm{pH}$ and (B) at high $\mathrm{pH}$.

\subsubsection{Influence of Contact Time}

Contact time is one of the effective factors in the batch adsorption process. Keeping other parameters including temperature $\left(25^{\circ} \mathrm{C}\right), \mathrm{pH} 5$, adsorbent dose $(1 \mathrm{~g} / 100 \mathrm{~mL})$, initial nickel concentration $(200 \mathrm{mg} / \mathrm{L})$ and agitation speed $(250 \mathrm{rpm})$ constant, the adsorption of nickel on glutamic-chitosan compounds was studied in the range 10-360 min. The effect of contact time on nickel adsorption efficiency is shown in Figure 5A. Adsorption rate initially increased rapidly, and the optimal removal efficiency was reached within $280 \mathrm{~min}$. No change in nickel concentration after 280-360 min was observed. The availability of sufficient vacant adsorbing sites in the beginning of the removal process is possibly the cause of the higher initial removal; afterwards, the removal percent rate decreased due to the limited vacant adsorption sites.

Figure 5B indicates that $\mathrm{Cu}$ (II) removal was increased from $50 \%$ to $92 \%$ as the contact time varied from $10 \mathrm{~min}$ to $360 \mathrm{~min}$. The optimum contact time for maximum removal (92\%) of $\mathrm{Cu}(\mathrm{II})$ was $300 \mathrm{~min}$.
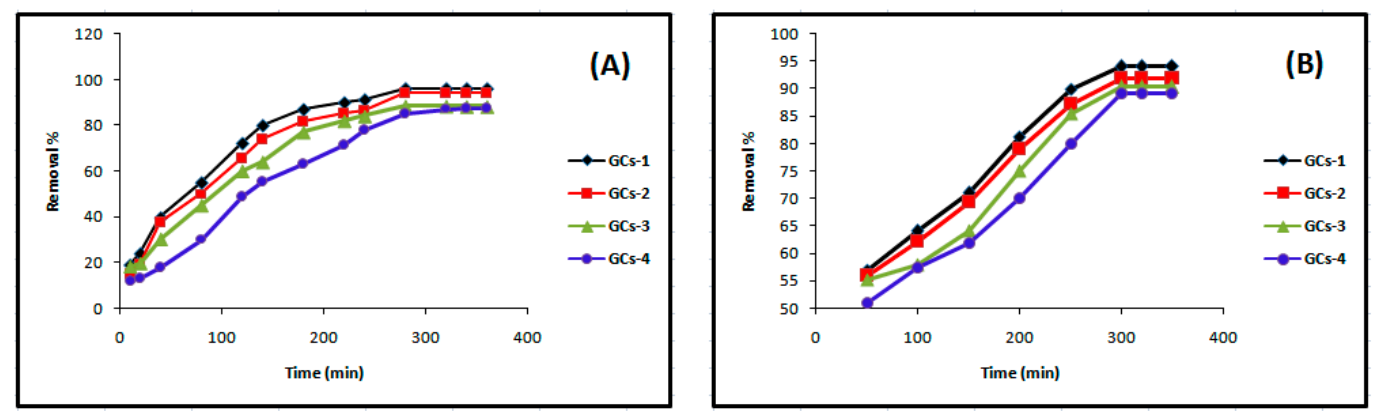

Figure 5. Influence of contact time on (A) nickel and (B) copper sorption.

\subsubsection{Influence of Initial Concentration}

The experimental results of the effect of initial nickel concentration on removal efficiency are presented in Figure 6A. The experiment was conducted using the volumes of solutions as $100 \mathrm{~mL}$, initial concentrations of metal as 5, 50, 100, 300, 500, 700, 900 and $1000 \mathrm{mg} / \mathrm{L}$ solution of $\mathrm{Ni}(\mathrm{II})$ in conical flasks, were gently shaken with $1 \mathrm{~g}$ of G-chitosan compounds for $60 \mathrm{~min}$ with $250 \mathrm{rpm}$ in the orbit mechanical shaker, with initial $\mathrm{pH}$ of the solution 5. Figure $6 \mathrm{~A}$ shows the nickel removal efficiency 
decreased with the increase in initial nickel concentration. In the case of low nickel concentrations, the ratio of the initial number of moles of nickel ions to the available surface area of adsorbent is large. However, at higher concentrations, the available sites of adsorption become fewer and hence the percentage removal of metal ions which depends on the initial concentration decreases [2]. The removal percentage decreases from $96 \%$ to $66 \%$ as the concentration increases.

The experimental results of the effect of initial copper concentration on removal efficiency were presented in Figure 6B, which showing that the copper removal efficiency decreased with the increase in initial copper concentration [19]. The removal percentage decreases from $92 \%-55 \%, 93 \%-56 \%$, $95 \%-58 \%$ and $97 \%-60 \%$ as the concentration increases.
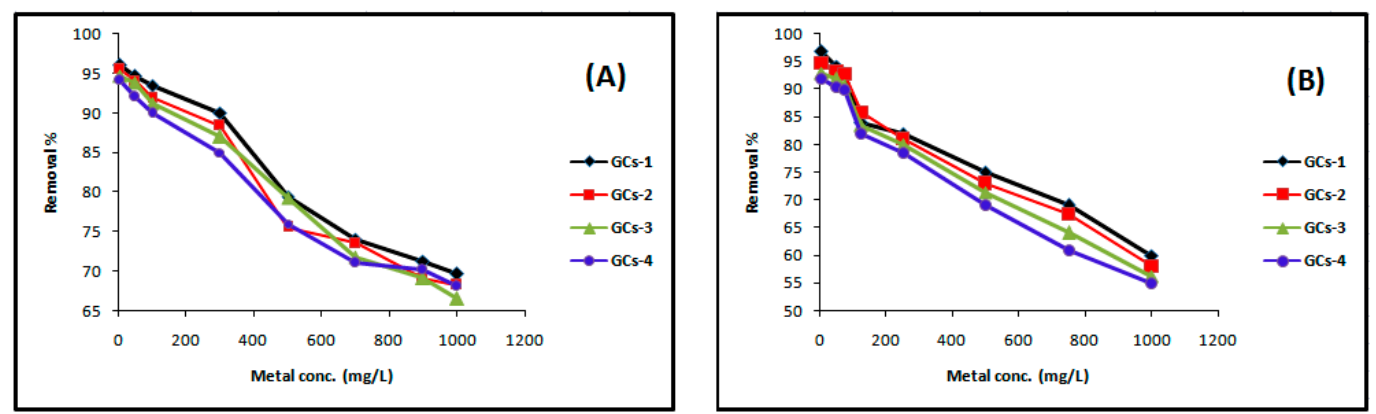

Figure 6. Influence of the initial concentration on (A) nickel and (B) copper sorption.

\subsection{Sorption Isotherm Studies}

\subsubsection{Langmuir Sorption Isotherm}

The maximum amount of $\mathrm{Ni}(\mathrm{II})$ or $\mathrm{Cu}(\mathrm{II})$ ion adsorption on the modified polymer is defined by the corresponding adsorption isotherms [17]. The Langmuir isotherm is based on the assumption that the adsorbent surface has sites with identical energy and has equal affinities for the adsorbate molecules, which mean that each adsorbate molecule is assumed to be located on a single site. Langmuir model predicts the formation of the monolayer of the adsorbate [20]. The experimental adsorption data are fitted according to the Langmuir isotherm models, from the equation:

$$
C_{e} / Q_{e}=C_{e} / Q_{m}+1 /\left(K_{L} \times Q_{m}\right)
$$

where $C_{e}$ is the equilibrium concentration of the adsorbate $(\mathrm{mg} / \mathrm{L}), Q_{m}$ is the maximum adsorption capacity of the adsorbent and $K_{L}$ is the Langmuir adsorption constant related to capacity and energy of adsorption, respectively; $Q_{e}$ is the adsorption quantity $(\mathrm{mg} / \mathrm{g}$ ) which calculated by the following equation:

$$
Q_{e}=\left[\left(C_{0}-C\right) V\right] / W
$$

where $C_{0}$ is the initial $\mathrm{Ni}(\mathrm{II})$ or $\mathrm{Cu}(\mathrm{II})$ concentration $(\mathrm{mg} / \mathrm{L}), C$ is final concentration after the adsorption; $V$ is the solution volume (L); and $W$ is the weight of the used adsorbent $(\mathrm{g})$.

Figure 7 shows the Langmuir adsorption isotherm of adsorption of nickel ions on chitosan derivatives GCs-1, GCs-2, GCs-3 and GCs-4 using Ni(II) concentrations (100-1300 mg/L) at pH 5 and $1 \mathrm{~g}$ of adsorbent, where Figure 8 shows the Langmuir adsorption isotherm of adsorption of copper ions on chitosan derivatives GCs-1, GCs-2, GCs-3 and GCs-4 using Cu(II) concentrations (75-1300 mg/L) at pH 5 and $1 \mathrm{~g}$ of adsorbent.

By plotting $C_{e} / Q_{e}$ versus $C_{e}$ as shown in Figures 7 and 8 for nickel and copper, respectively; it was found that the experimental adsorption data are fitted according to the Langmuir isotherm models with correlation coefficient values $R^{2}=(0.998,0.951,0.974,0.947)$ and $(0.999,0.901,0.967,0.993)$ for $\mathrm{Ni}(\mathrm{II})$ and $\mathrm{Cu}(\mathrm{II})$, respectively. Both $Q_{m}$ and $K_{L}$ can be calculated from the slope and the intercept of the linear plot in which; slope $=1 / Q_{m}$ and intercept $=1 / Q_{m} \times K_{L}$. The fitting result showed that 
the maximum sorption capacity $Q_{m}$ of polymer adsorbent reached $103.4 \mathrm{mg} / \mathrm{g}$ in case of $\mathrm{Ni}$ (II) and $83.33 \mathrm{mg} / \mathrm{g}$ in case of $\mathrm{Cu}$ (II), these results confirm the applicability of Langmuir model which suggests that the adsorption was taken place as mono layer adsorption.
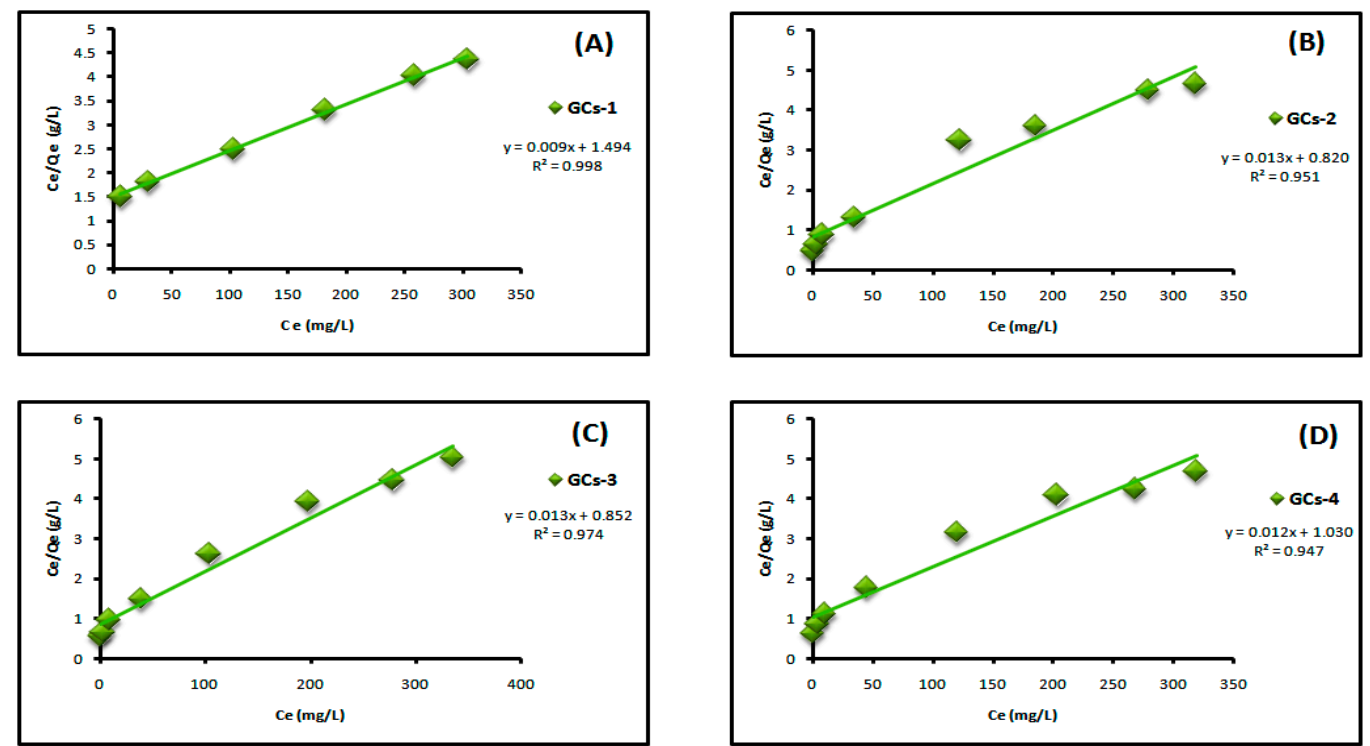

Figure 7. Langmuir isotherm for Ni(II) adsorption using (A) GCs-1; (B) GCs-2; (C) GCs-3 and (D) GCs-4.
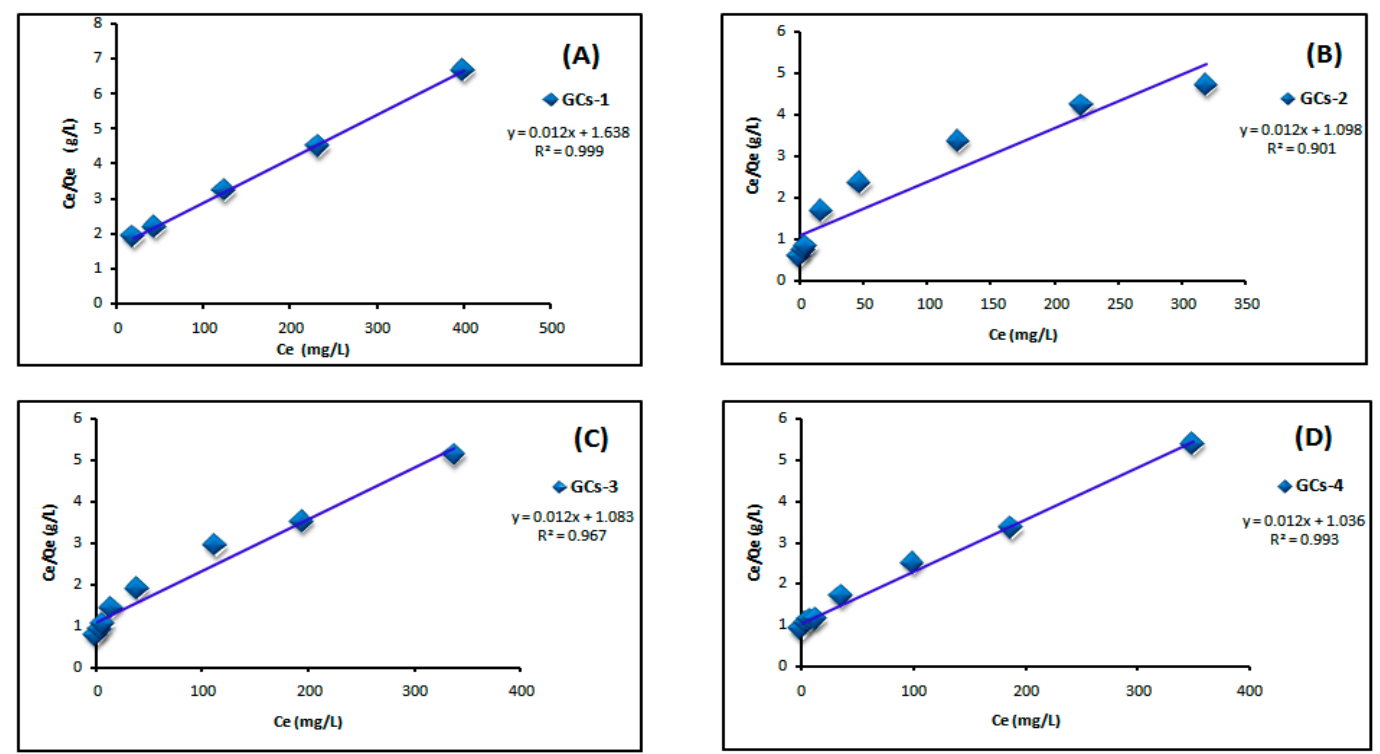

Figure 8. Langmuir isotherm for $\mathrm{Cu}(\mathrm{II})$ adsorption using (A) GCs-1; (B) GCs-2; (C) GCs-3 and (D) GCs-4.

\subsubsection{Freundlich Sorption Isotherm}

Surface heterogenty of the sorbent is indicated from Freundlich model which represented by the following equation:

$$
\log Q_{e}=\log K_{f}+1 / n \times \log C_{e}
$$

where $Q_{e}$ is the adsorbed amount at equilibrium $(\mathrm{mg} / \mathrm{g}), C_{e}$ is the equilibrium concentration of $\mathrm{Cu}$ (II) or $\mathrm{Ni}(\mathrm{II})(\mathrm{mg} / \mathrm{L}), K_{f}$ is Freundlich constant, $1 / n$ is Freundlich exponent. Both constants were calculated from the slope and intercept of the plotting between $\log Q_{e}$ and $\log C_{e}$. Linear plot of $\log C_{e} v s$. $\log Q_{e}$ confirm the applicability of Freundlich model as shown in Figures 9 and 10. It means that the 
adsorption was taken place at a heterogeneous surface; however nickel and copper adsorption on glutamic-chitosan are fitted to both models since the correlation coefficients values are very close.
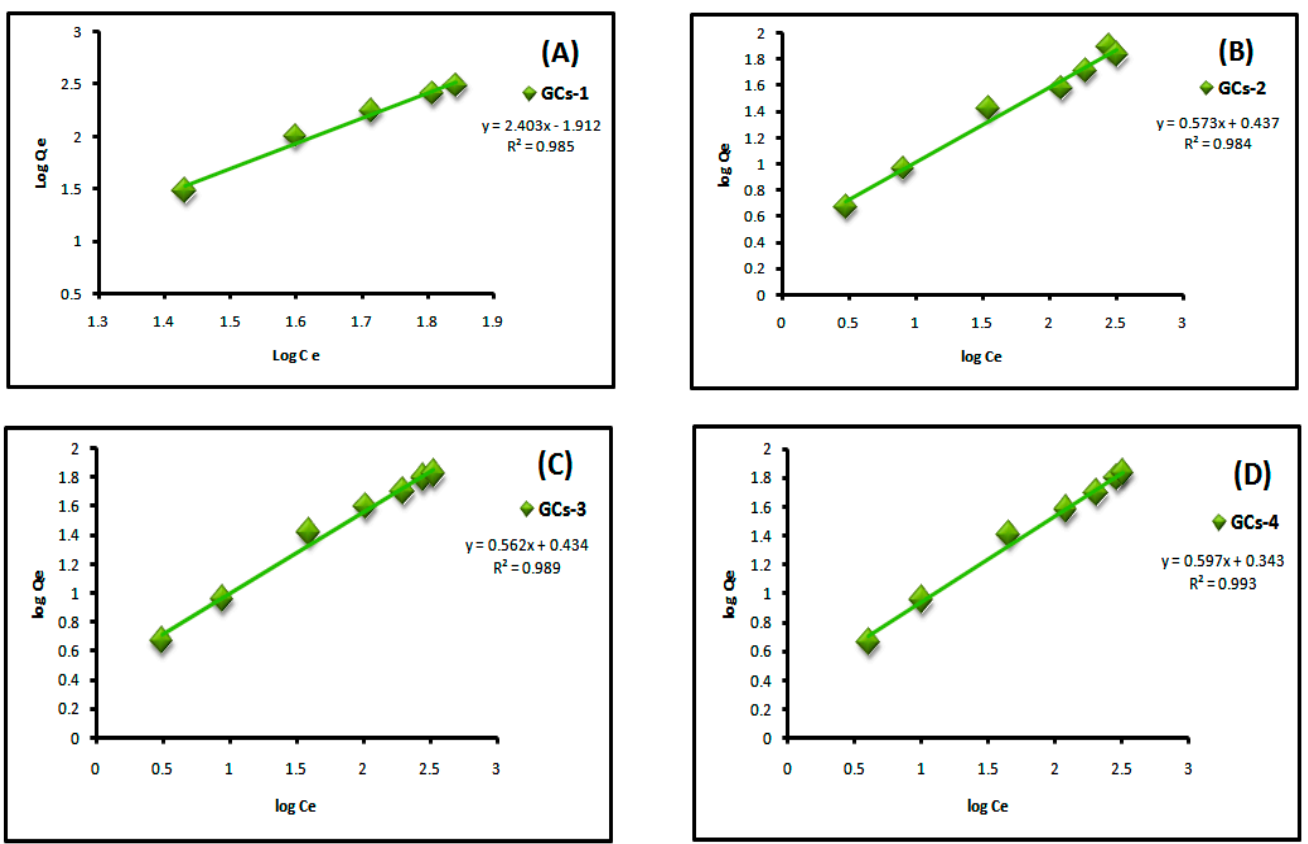

Figure 9. Freundlich plot for Ni(II) adsorption on to (A) GCs-1; (B) GCs-2; (C) GCs-3 and (D) GCs-4.
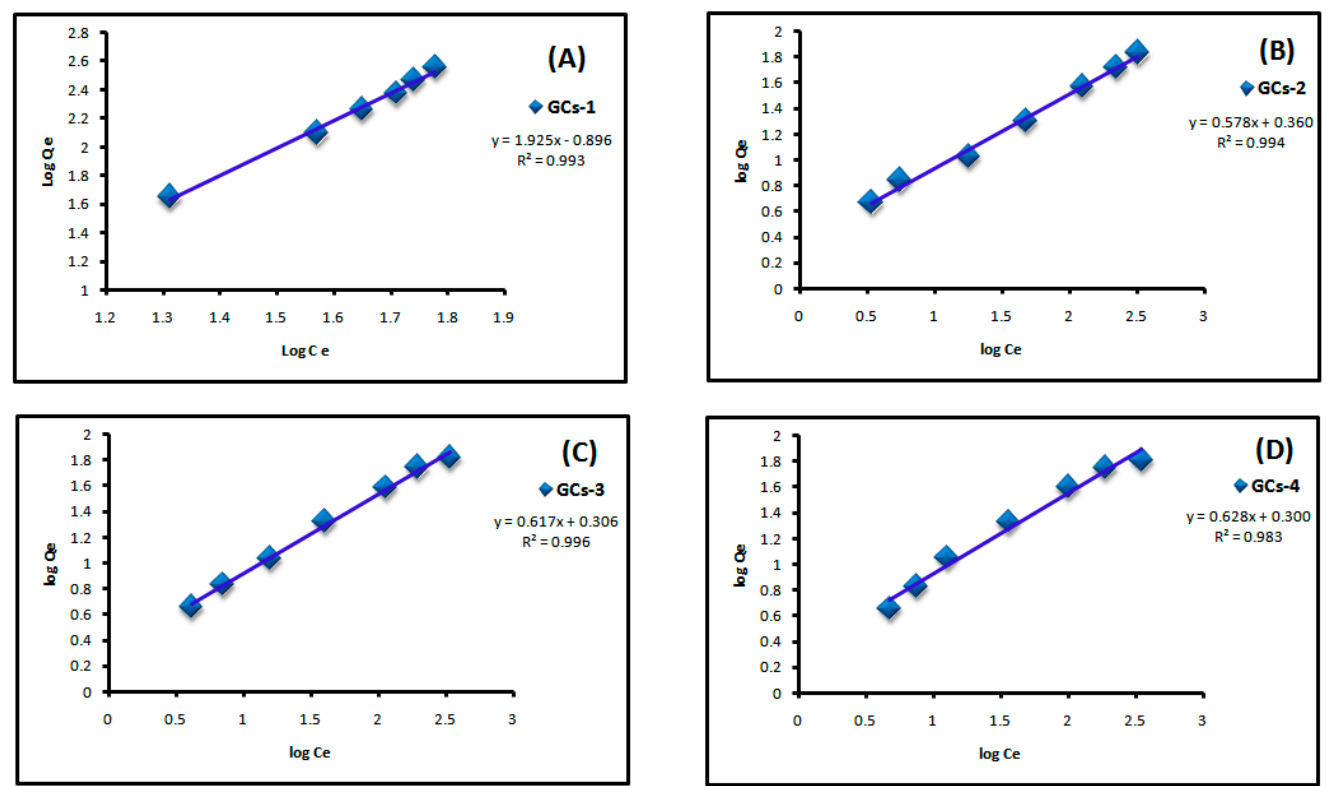

Figure 10. Freundlich plot for $\mathrm{Cu}(\mathrm{II})$ adsorption on to (A) GCs-1; (B) GCs-2; (C) GCs-3 and (D) GCs-4.

\subsection{Kinetics Studies}

The kinetic parameters for the adsorption process were studied for contact time from $10 \mathrm{~min}$ to 360 min by monitoring separately the percentages of removal of the $\mathrm{Cu}(\mathrm{II})$ and $\mathrm{Ni}(\mathrm{II})$. Pseudo-first order kinetics are represented by Equation (4), while the pseudo-second order ones are represented by Equation (5) [20]:

$$
\ln \left(Q_{e}-Q_{t}\right)=-k_{1} t+\ln Q_{e}
$$




$$
t / Q_{t}=1 / k_{2} \times Q_{e}^{2} \times t+t / Q_{e}
$$

where $Q_{e}$ and $Q_{t}$ : are the amount of metal adsorbed $(\mathrm{mg} / \mathrm{g})$ at equilibrium and at time $t(\mathrm{~min}), k_{1}$ $\left(\mathrm{min}^{-1}\right)$ and $k_{2}\left(\mathrm{~g} \cdot \mathrm{mg}^{-1} \cdot \mathrm{min}^{-1}\right)$ are the adsorption rate constant of pseudo-first order, pseudo-second order adsorption kinetics, respectively. The values of $k_{1}$ can be determined from the slope of the linear plot of $\ln \left(Q_{e}-Q_{t}\right) v s . t$, and $k_{2}$ can be calculated from the slope of the linear plot of $t / Q_{t} v s$. $t$.

The linear plots of the two kinetic models of $\mathrm{Ni}(\mathrm{II})$ are presented in Figures 11 and 12 respectively. Table 3 showed the values of $k_{1}, k_{2}, Q_{e}$ and the correlation coefficient $\left(R^{2}\right)$ from the linear plots. The pseudo-second order linear plots of $\mathrm{Ni}$ (II) resulted in higher $R^{2}$ values than the pseudo-first order. These indicated better applicability of the pseudo-second order model, which relies on the assumption that chemisorptions are the rate limiting step.
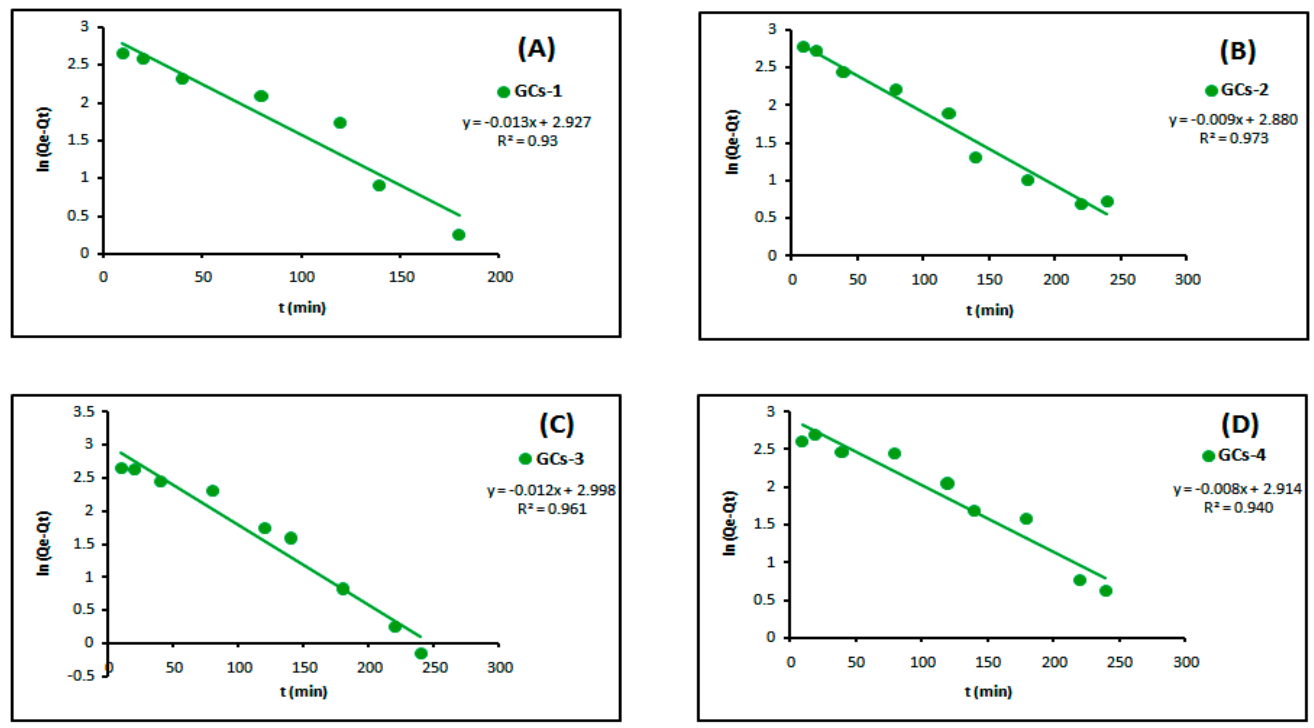

Figure 11. Pseudo-first order kinetics models of nickel adsorption using (A) GCs-1; (B) GCs-2; (C) GCs-3 and (D) GCs-4.
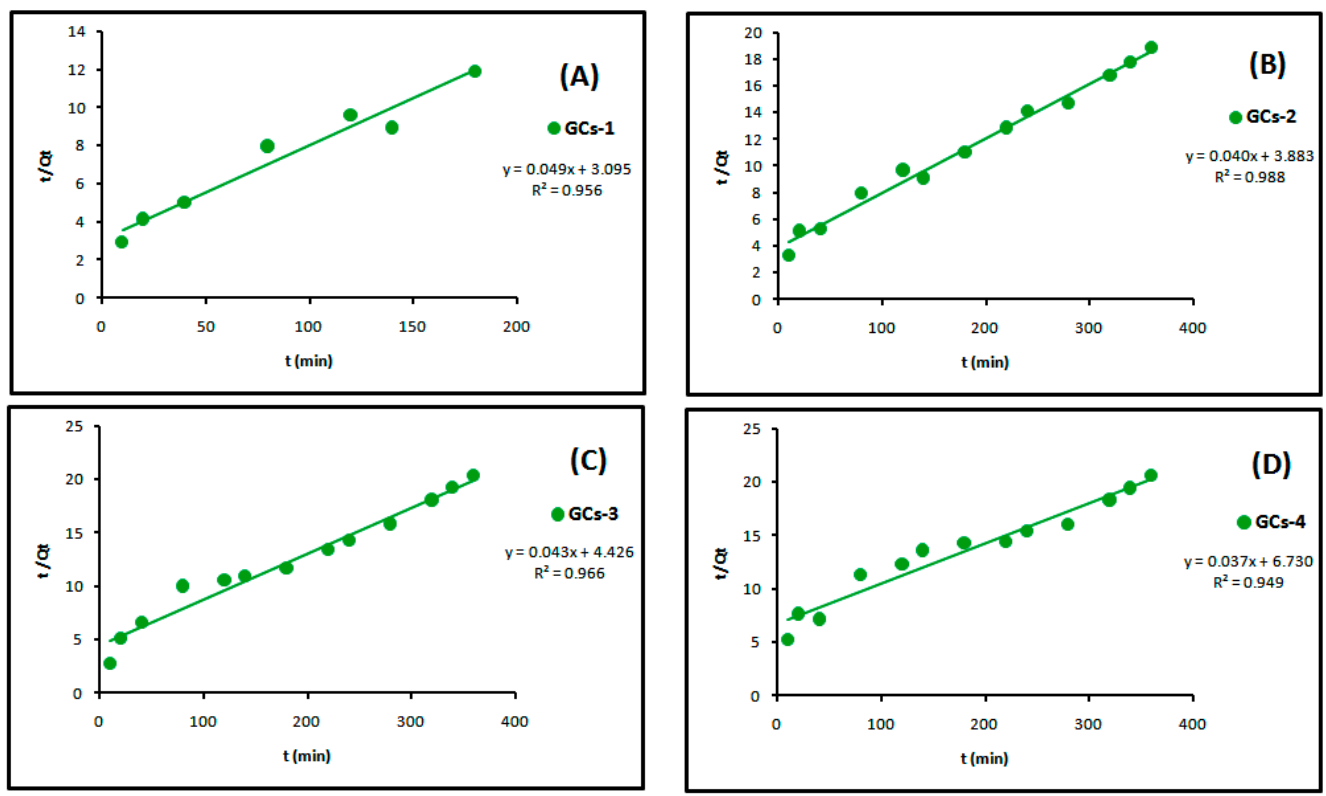

Figure 12. Pseudo-second order kinetics models of nickel adsorption using (A) GCs-1; (B) GCs-2; (C) GCs-3 and (D) GCs-4. 
Table 3. Constants and correlation coefficient of pseudo-first order and pseudo-second order kinetics of nickel adsorption.

\begin{tabular}{|c|c|c|c|c|c|c|c|}
\hline \multirow{2}{*}{ Metal Ion } & \multicolumn{3}{|c|}{ Pseudo-First Order Model } & \multirow{2}{*}{$\begin{array}{c}\text { Experimental Value } \\
Q_{e}(\mathrm{mg} / \mathrm{g})\end{array}$} & \multicolumn{3}{|c|}{ Pseudo-Second Order Model } \\
\hline & $Q_{e}(\mathrm{mg} / \mathrm{g})$ & $k_{1}\left(\min ^{-1}\right)$ & $R^{2}$ & & $Q_{e}(\mathrm{mg} / \mathrm{g})$ & $k_{2}\left(\mathrm{~g} \cdot \mathrm{mg}^{-1} \cdot \min ^{-1}\right)$ & $R^{2}$ \\
\hline GCs-1 & 20.32 & 0.013 & 0.930 & 18.08 & 18.67 & 0.005 & 0.956 \\
\hline GCs-2 & 25.00 & 0.009 & 0.973 & 19.06 & 17.81 & 0.004 & 0.988 \\
\hline GCs-3 & 23.26 & 0.012 & 0.961 & 17.68 & 20.05 & 0.004 & 0.966 \\
\hline GCs-4 & 27.03 & 0.008 & 0.940 & 17.46 & 18.43 & 0.002 & 0.949 \\
\hline
\end{tabular}

The linear plots of the two kinetic models of $\mathrm{Cu}(\mathrm{II})$ are presented in Figures 13 and 14 . Table 4 showed the values of $k_{1}, k_{2}, Q_{e}$ and the correlation coefficient $\left(R^{2}\right)$ from the linear plots. The pseudo-second order linear plots of $\mathrm{Cu}$ (II) resulted in higher $R^{2}$ values than the pseudo-first order.

Table 4. Constants and correlation coefficient of pseudo-first order and pseudo-second order kinetics of copper adsorption.

\begin{tabular}{|c|c|c|c|c|c|c|c|}
\hline \multirow{2}{*}{ Metal Ion } & \multicolumn{3}{|c|}{ Pseudo-First Order Model } & \multirow{2}{*}{$\begin{array}{c}\text { Experimental Value } \\
Q_{e}(\mathrm{mg} / \mathrm{g})\end{array}$} & \multicolumn{3}{|c|}{ Pseudo-Second Order Model } \\
\hline & $Q_{e}(\mathrm{mg} / \mathrm{g})$ & $k_{1}\left(\min ^{-1}\right)$ & $R^{2}$ & & $Q_{e}(\mathrm{mg} / \mathrm{g})$ & $k_{2}\left(g \cdot \mathrm{mg}^{-1} \min ^{-1}\right)$ & $R^{2}$ \\
\hline GCs-1 & 12.99 & 0.007 & 0.974 & 18.8 & 19.01 & 0.009 & 0.989 \\
\hline GCs-2 & 14.73 & 0.009 & 0.895 & 18.4 & 21.20 & 0.006 & 0.975 \\
\hline GCs-3 & 15.26 & 0.009 & 0.829 & 18.06 & 20.73 & 0.005 & 0.963 \\
\hline GCs-4 & 12.31 & 0.005 & 0.890 & 17.84 & 21.30 & 0.004 & 0.954 \\
\hline
\end{tabular}
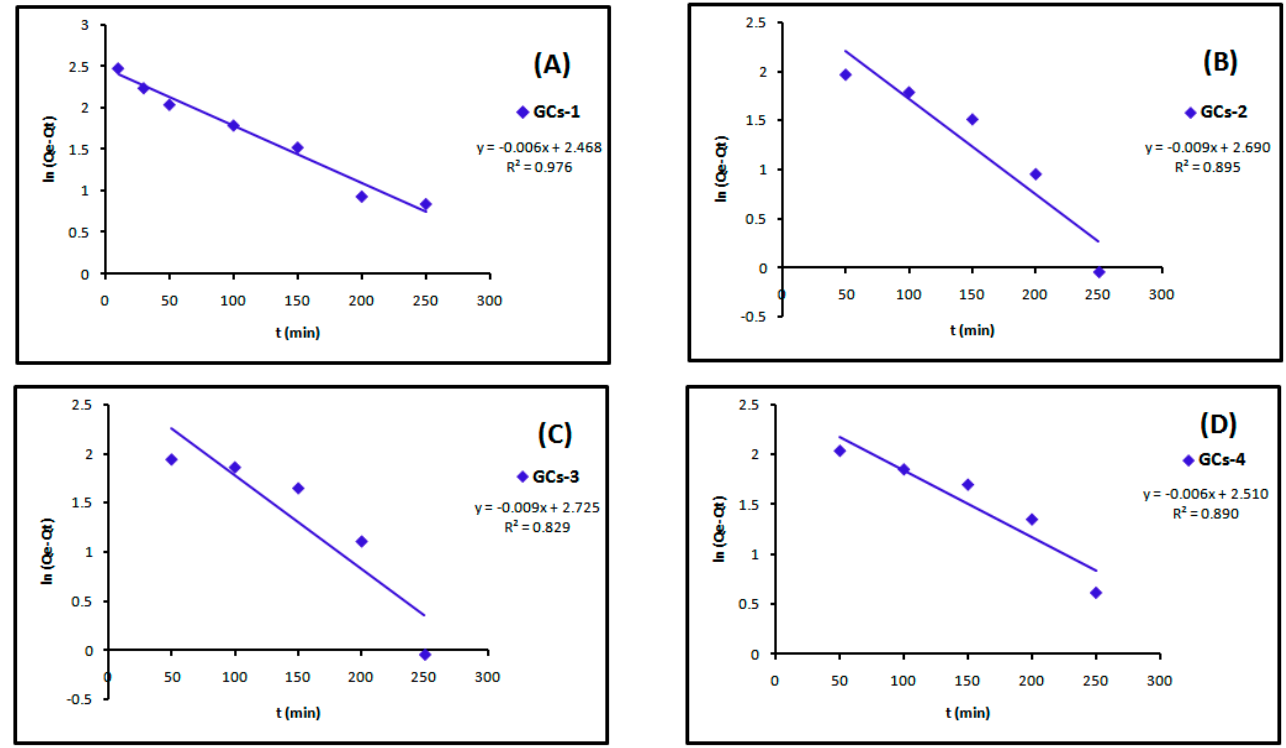

Figure 13. Pseudo-first order kinetics models of copper adsorption using (A) GCs-1; (B) GCs-2; (C) GCs-3 and (D) GCs-4.
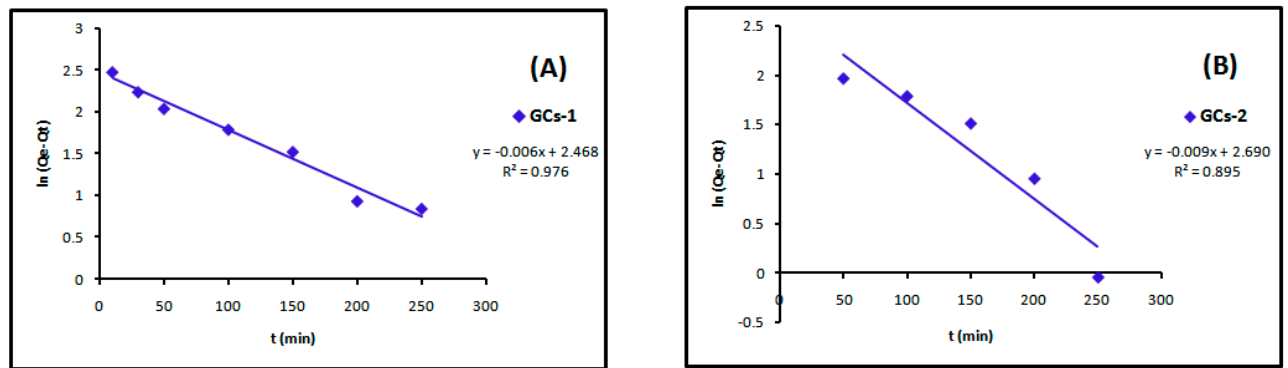

Figure 14. Cont. 

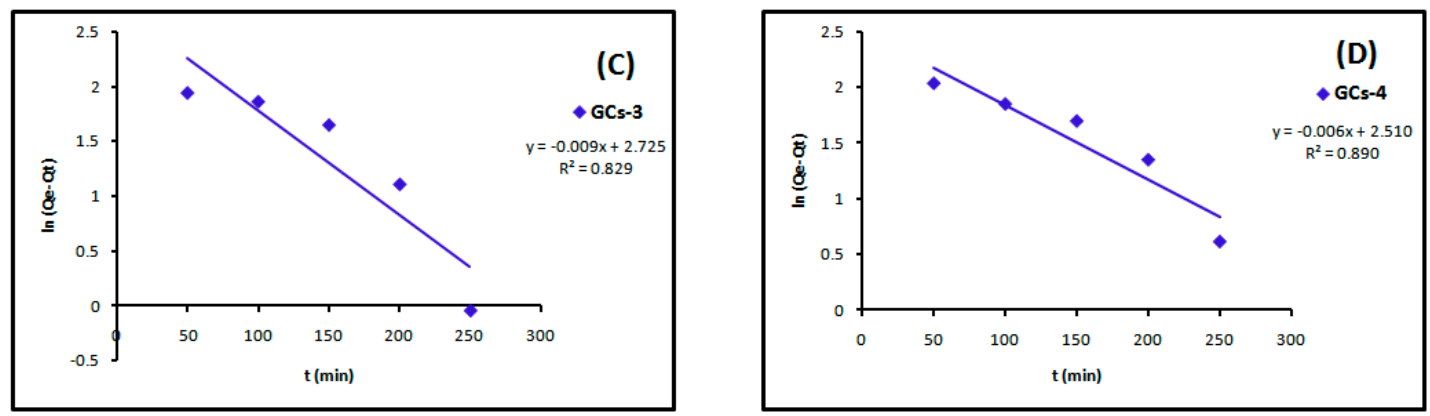

Figure 14. Pseudo-second order kinetics models of copper adsorption using (A) GCs-1; (B) GCs-2;

(C) GCs-3 and (D) GCs-4.

\subsection{Desorption Studies of $\mathrm{Ni}(\mathrm{II})$ and $\mathrm{Cu}(\mathrm{II})$}

The sorbed $\mathrm{Ni}$ and $\mathrm{Cu}$ were dried and preserved. For desorption $\mathrm{Cu}$ and Ni-sorbed chitosan were shaken with dilute hydrochloric acid $(0.5 \mathrm{M})$ for $1 \mathrm{~h}$ at room temperature and filtered. The filtrate was analyzed for the oxidation states of $\mathrm{Cu}$ and Ni using UV-Visible spectrophotometry in the wavelength ranges $190 \mathrm{~nm}-1100 \mathrm{~nm}$.

\section{Materials and Methods}

\subsection{Materials}

Chitosan was purchased from Acros Organics (Morris Plains, NJ, USA). Its deacetylation degree is $88 \%$ and its average molecular weight is $100,000-300,000 \mathrm{Da}$. Glutamic acid, acetic acid, and methanol, were of analytical grade from Aldrich (Saint Louis, MO, USA) and used as received.

\subsection{Measurements}

Fourier transform infrared (FTIR) spectra were recorded using $\mathrm{KBr}$ discs on a Perkin Elmer spectrometer (Perkin-Elmer, Waltham, MA, USA) at room temperature in the range of $4000-400 \mathrm{~cm}^{-1}$. Elemental analyses of the prepared derivatives were done in a Model 2410-Series II C, H, N, S Analyzer (Perkin-Elmer, Shelton, CT, USA). ${ }^{1} \mathrm{H}-\mathrm{NMR}$ spectra were recorded using a Gemini-300 MHz instrument (Gemini, Palo Alto, CA, USA), in DMSO- $d_{6}$ as a solvent at $25^{\circ} \mathrm{C}$. Chemical shifts $(\delta)$ are expressed in parts per million (ppm) from tetramethylsilane as an internal standard. The morphology of the cross-linking gel was analyzed with a JEOL-JSM 5300 Scanning electron microscope (JEOL, Tokyo, Japan); metal solutions were analyzed using a Model U-2800 UV-Visible spectrophotometer (Hitachi, Schaumburg, IL, USA). Ni(II) and $\mathrm{Cu}$ (II) concentrations were measured using a Thermo-Scientific ICE-3300 Atomic adsorption spectrometer AAs (Thermo-Scientific, Waltham, MA, USA).

\subsection{General Procedures for Chitosan-Glutamic Synthesis}

A solution of glutamic acid in distilled water $(20 \mathrm{~mL})$ was added to chitosan $(20 \mathrm{mmol})$ in distilled water $(30 \mathrm{~mL})$. The mixture was stirred for $4 \mathrm{~h}$ at $60^{\circ} \mathrm{C}$. After cooling, the homogenous cross-linked hydrogels which formed was submerged in methanol for $12 \mathrm{~h}$ for dewatering to give white product; the dewatering hydrogel was filtered and dried at $60^{\circ} \mathrm{C}$ to constant weight.

G-chitosan-1: Obtained from glutamic acid (2.5 mmol) in 96.4\% yield; IR (KBr): 1568 (CONH), 1631 $(\mathrm{CONH}), 2867,2925\left(\mathrm{NH}_{2}\right), 3437 \mathrm{~cm}^{-1}(\mathrm{NH}),(\mathrm{OH}),{ }^{1} \mathrm{H}-\mathrm{NMR}(\delta, \mathrm{ppm})\left(\mathrm{DMSO}-d_{6}\right) \delta: 1.88(\mathrm{q}, 2 \mathrm{H}$, $\mathrm{CH}_{2}$-glutamic), $2.11\left(\mathrm{~m}, 1 \mathrm{H}, \mathrm{H}-5^{\prime}\right), 2.29\left(\mathrm{~m}, 2 \mathrm{H}, \mathrm{H}-1^{\prime}, \mathrm{H}-2^{\prime}\right), 2.35\left(\mathrm{t}, 2 \mathrm{H}, \mathrm{CH}_{2} \mathrm{CO}\right), 2.60\left(\mathrm{~m}, 2 \mathrm{H}, \mathrm{H}-3^{\prime}\right.$, $\left.\mathrm{H}-4^{\prime}\right), 2.61$ (m, 2H, H-6a' $\left.{ }^{\prime} \mathrm{H}_{-}-6 \mathrm{~b}^{\prime}\right), 3.27$ (t, 1H, CH-CO), 3.29 (bs, $\mathrm{NH}_{2}, \mathrm{OH}^{\prime}$; exchangeable with $\mathrm{D}_{2} \mathrm{O}$ ), $4.00\left(\mathrm{~m}, 1 \mathrm{H}, \mathrm{OH}\right.$; exchangeable with $\left.\mathrm{D}_{2} \mathrm{O}\right), 7.77\left(\mathrm{~s}, 2 \mathrm{H}, 2 \mathrm{NH}\right.$; exchangeable with $\left.\mathrm{D}_{2} \mathrm{O}\right)$. Anal. Found: C, 47.80; H, 7.15; N, 7.69. 
G-chitosan-2: Obtained from glutamic acid (5 mmol) in 92.5\% yield; IR (KBr): $1638(\mathrm{CONH}),\left(\mathrm{NH}_{2}\right)$, $3445 \mathrm{~cm}^{-1}(\mathrm{NH}),(\mathrm{OH})$; Anal. Found: $\mathrm{C}, 47.84 ; \mathrm{H}, 7.24 ; \mathrm{N}, 7.72$.

G-chitosan-3: Obtained from glutamic acid $(10 \mathrm{mmol})$ in $90.2 \%$ yield; IR $(\mathrm{KBr}): 1636(\mathrm{CONH})$, 2925 (saturated C-H), $\left(\mathrm{NH}_{2}\right), 3728,3434 \mathrm{~cm}^{-1}(\mathrm{NH}),(\mathrm{OH})$; Anal. Found: $\mathrm{C}, 47.86 ; \mathrm{H}, 7.27 ; \mathrm{N}, 7.74$

G-chitosan-4: Obtained from glutamic acid $(20 \mathrm{mmol})$ in $89 \%$ yield; IR $(\mathrm{KBr})$ : $1637(\mathrm{CONH})$, 2925 (saturated C-H), $\mathrm{NH}_{2}, 3438 \mathrm{~cm}^{-1}(\mathrm{NH}),(\mathrm{OH})$; Anal. Found: $\mathrm{C}, 47.88 ; \mathrm{H}, 7.35 ; \mathrm{N}, 7.77$.

\subsection{Stock Solution Preparation}

Stock solution of $10 \mathrm{mg} / \mathrm{L} \mathrm{Cu}(\mathrm{II})$ ion was prepared by dissolving copper sulphate pentahydrate $\left(\mathrm{CuSO}_{4} \cdot 5 \mathrm{H}_{2} \mathrm{O}, 39.28 \mathrm{mg}\right)$ in distilled water $(1000 \mathrm{~mL})$ contained in a volumetric flask. Ni(II) stock solution of $10 \mathrm{mg} / \mathrm{L}$ concentration was also prepared by dissolving nickel sulphate hexahydrate $\left(\mathrm{NiSO}_{4} \cdot 6 \mathrm{H}_{2} \mathrm{O}, 43.96 \mathrm{mg}\right)$ in $1000 \mathrm{~mL}$ distilled water. Hydrochloric acid and sodium hydroxide were used to adjust the solution $\mathrm{pH}$. Distilled water was used throughout the experimental work.

\subsection{Adsorption Experiments}

Sorption experiments were conducted in $250 \mathrm{~mL}$ conical flasks containing $100 \mathrm{~mL}$ of various concentrations of $\mathrm{Ni}$ (II) or $\mathrm{Cu}$ (II) solution using accurately weighed chitosan. The flasks were agitated in an orbit shaker at $100 \mathrm{rpm}$ and at room temperature $\left(25^{\circ} \mathrm{C}\right)$. The initial and final concentrations of the solutions were measured by atomic adsorption (AAS) at the maximum adsorption wavelength and the adsorption capacities of the adsorbent were calculated.

The percent removal of metals from the solution was calculated by the following equation [20]:

$$
\% \text { removal }=\frac{C_{0}-C}{C_{0}} \times 100
$$

where $C_{0}(\mathrm{mg} / \mathrm{L})$ is the initial metal ion concentration and $C(\mathrm{mg} / \mathrm{L})$ is the final metal ion concentration in the solution.

The effect of sorbent dosage was studied from $1 \mathrm{~g}$ to $5 \mathrm{~g}$ for $1 \mathrm{~h}$ contact time. Effect of initial $\mathrm{pH}$ on the sorption capacity of sorbent for $\mathrm{Ni}$ (II) and $\mathrm{Cu}$ (II) was studied by varying solution $\mathrm{pH}$ from 3 to 9 at the sorbent dosage of $1 \mathrm{~g} / 100 \mathrm{~mL}$ for $1 \mathrm{~h}$ contact time using $200 \mathrm{mg} / \mathrm{L}$ initial $\mathrm{Ni}$ and $\mathrm{Cu}$ concentration; the solution $\mathrm{pH}$ was adjusted with dilute $\mathrm{HCl}$ or $\mathrm{NaOH}$ solution. The effect of contact time on the sorption capacity of sorbent was studied in the range 25-350 min at an initial $\mathrm{Ni}$ and $\mathrm{Cu}$ concentration of $200 \mathrm{mg} / \mathrm{L}$. The effect of initial concentration on the sorption capacity of sorbent was studied using the volume of solutions as $100 \mathrm{~mL}$, and initial concentration of nickel as 5, 50, 100, 300, 500, 700, 900 and $1000 \mathrm{mg} / \mathrm{L}$; and copper as 5, 50, 75, 125, 250, 500, 750 and $1000 \mathrm{mg} / \mathrm{L}$. Adsorption isotherms were studied at different initial $\mathrm{Ni}, \mathrm{Cu}$ concentrations at room temperature.

\section{Conclusions}

Chitosan-glutamic hydrogels were synthesized by modification of chitosan with glutamic acid which was characterized with FTIR, ${ }^{1} \mathrm{H}-\mathrm{NMR}$, elemental analysis and SEM. The influence of adsorbent dosage, solution $\mathrm{pH}$ value, reaction time and initial concentration of $\mathrm{Ni}(\mathrm{II})$ and $\mathrm{Cu}(\mathrm{II})$ on the adsorption capacity were investigated. The results indicate that chitosan-glutamic derivatives are good adsorbents of $\mathrm{Ni}(\mathrm{II})$ and $\mathrm{Cu}(\mathrm{II})$.

Acknowledgments: This research was partially supported by the Chemistry Department, Faculty of Science, Alexandria University. Authors also wish to thank Sh. El Shazly for his valuable discussions. Thanks are also for the reviewers and editor for their helpful suggestions and enlightening comments.

Author Contributions: Mohamed M. El Sadek suggested and supervised the work and performed the article editing. Mohamed A. Mostafa and Seham Y. Hassan conceived and designed the experiments and analyzed the data. Huda E. Abdelwahab performed the experiments.

Conflicts of Interest: The authors declare no conflict of interest. 


\section{References}

1. Neylan, D. Accumulation of Heavy Metals in Freshwater Organisms: Assessment of Toxic Interactions. Turk. J. Chem. 2001, 25, 173-179.

2. Wan, N.W.S.; Teong, L.C.; Hanafiah, K.M. Adsorption of dyes and heavy metal ions by chitosan composites: A review. Carbohydr. Polym. 2011, 83, 1446-1456.

3. Santino, O.L.C. Assessment of quality of air in Palermo by chemical (ICP-OES) and cytological analyses on leaves of Eucalyptus camaldulensis. Environ. Sci. Pollut. Res. Int. 2015, 22, 1891-1905.

4. Boddu, V.M.; Abburi, K.; Randolph, A.J.; Smith, E.D. Removal of Copper(II) and Nickel(II) Ions from Aqueous Solutions by a Composite Chitosan Biosorbent. Sep. Sci. Technol. 2008, 43, 1365-1381. [CrossRef]

5. Chervona, Y.; Arita, A.; Costa, M. Carcinogenic metals and the epigenome: Understanding the effect of nickel, arsenic, and chromium. Metallomics Integr. Biometal Sci. 2012, 4, 619-627. [CrossRef] [PubMed]

6. Das, K.K.; Das, S.N.; Dhundasi, S.A. Nickel, its adverse health effects \& oxidative stress. Indian J. Med. Res. 2008, 128, 412-425. [PubMed]

7. Awual, M.R. A novel facial composite adsorbent for enhanced copper(II) detection and removal from wastewater. Chem. Eng. J. 2015, 266, 368-375. [CrossRef]

8. Tabrizi, A.B. Development of a cloud point extraction-spectrofluorimetric method for trace copper(II) determination in water samples and parenteral solutions. J. Hazard. Mater. 2007, 139, 260-264. [CrossRef] [PubMed]

9. Awual, M.R.; Ismael, M.; Yaita, T.; El-Safty, S.A.; Shiwaku, H.; Okamoto, Y.; Suzuki, S. Trace copper(II) ions detection and removal from water using novel ligand modified composite adsorbent. Chem. Eng. J. 2013, 222, 67-76. [CrossRef]

10. Bo, C.; Ping, Z. A new determining method of copper(II) ions at $\mathrm{ng} \cdot \mathrm{mL}^{-1}$ levels based on quenching of the water-soluble nanocrystals fluorescence. Anal. Bioanal. Chem. 2005, 381, 986-992. [CrossRef] [PubMed]

11. Chen, H.; Dai, G.; Zhao, J.; Zhong, A.; Wu, J.; Yan, H. Removal of copper(II) ions by a biosorbent-Cinnamomum camphora leaves powder. J. Hazard. Mater. 2010, 177, 228-236. [CrossRef] [PubMed]

12. Boddu, V.M.; Abburi, K.; Talbott, J.L.; Smith, E.D. Removal of hexavalent chromium from wastewater using a new composite chitosan biosorbent. Environ. Sci. Technol. 2003, 37, 4449-4456. [CrossRef] [PubMed]

13. Cataldo, S.; Muratore, N.; Orecchio, S.; Pettignano, A. Enhancement of adsorption ability of calcium alginate gel beads towards $\mathrm{Pd}(\mathrm{II})$ ion. A kinetic and equilibrium study on hybrid Laponite and Montmorillonite-alginate gel beads. Appl. Clay Sci. 2015, 118, 162-170. [CrossRef]

14. Rinaudo, M. Chitin and chitosan: Properties and applications. Prog. Polym. Sci. 2006, 31, 603-632. [CrossRef]

15. Roberts, G.A.F. Chitin Chemistry; Macmillan Education: London, UK, 1992.

16. Kyzas, G.Z.; Bikiaris, D.N. Recent modifications of chitosan for adsorption applications: A critical and systematic review. Mar. Drugs 2015, 13, 312-337. [CrossRef] [PubMed]

17. Junli, Z. Synthesis, characterization and adsorption properties of a novel chitosan derivative. Indian J. Chem. Technol. 2012, 19, 161-166.

18. Pavia, D.L.; Lampman, G.L.; Kriz, G.S.; Vyvyan, J.R. Introduction to Spectroscopy, 5th ed.; Cengage Learning: Belmont, CA, USA, 2015.

19. Dehonor, G.M.; Hernández, E.M.; Ruiz, T.F.A.; Contreras-Reyes, R. Properties and adsorptive capacity of amino acids modified chitosans for copper ion removal. Macromol. Symp. 2003, 197, 277-288. [CrossRef]

20. Sivakami, M.S.; Gomathi, T.; Venkatesan, J.; Jeong, H.S.; Kim, S.K.; Sudha, P.N. Preparation and characterization of nano chitosan for treatment wastewaters. Int. J. Biol. Macromol. 2013, 57, $204-212$. [CrossRef] [PubMed]

Sample Availability: Samples are not available.

(C) 2016 by the authors; licensee MDPI, Basel, Switzerland. This article is an open access article distributed under the terms and conditions of the Creative Commons Attribution (CC-BY) license (http://creativecommons.org/licenses/by/4.0/). 